\title{
"Empirical evidence of market reactions based on signaling theory in Indonesia stock exchange"
}

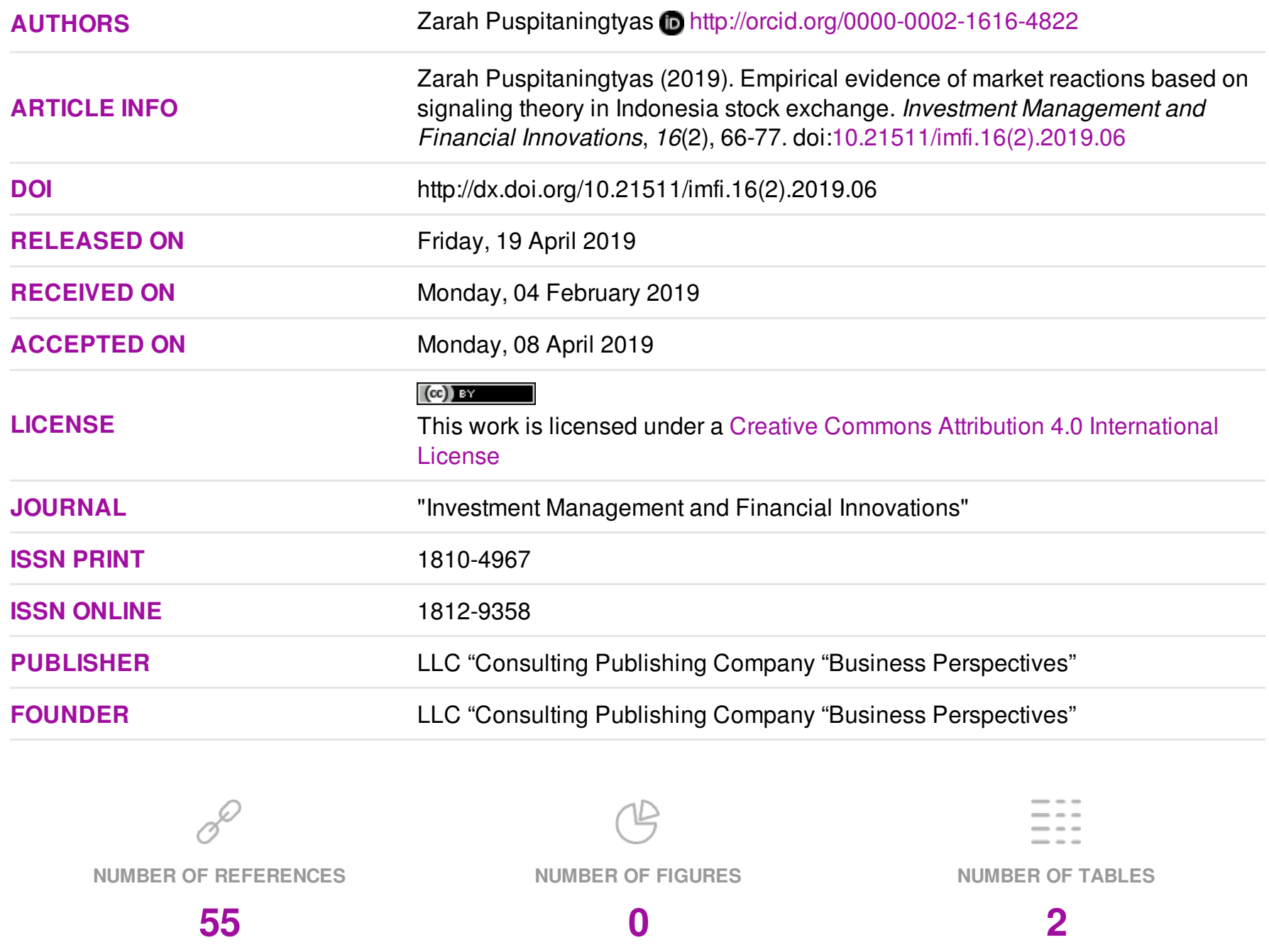

(C) The author(s) 2022. This publication is an open access article. 


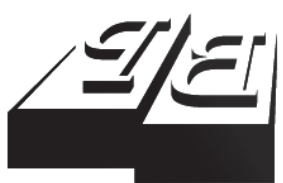

BUSINESS PERSPECTIVES

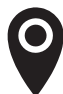

LLC "CPC "Business Perspectives" Hryhorii Skovoroda lane, 10, Sumy, 40022, Ukraine

www.businessperspectives.org

Received on: $4^{\text {th }}$ of February, 2019 Accepted on: $8^{\text {th }}$ of April, 2019

(C) Zarah Puspitaningtyas, 2019

Zarah Puspitaningtyas, Doctor, Lecturer, University of Jember, Indonesia.

\title{
EMPIRICAL EVIDENCE OF MARKET REACTIONS BASED ON SIGNALING THEORY IN INDONESIA STOCK EXCHANGE
}

\begin{abstract}
Signaling theory assumes that it is necessary to signal investors to how they perceive company's prospects. One of them is dividend announcements. The announcement of dividends is predicted to be a signal for investors in the investment decision making process. This study aims to determine and analyze the effect of dividend announcements, both increases and decreases in dividends, on stock returns. This study is intended to find empirical evidence about market reactions based on signaling theory in Indonesia Stock Exchange on the period 2017. The analysis of this study uses the event study method and hypothesis testing carried out using different test paired sample $\mathrm{t}$-test. The results of this study prove that the market reacts to the announcement of dividends. The market reaction is indicated by the value of abnormal returns, namely abnormal returns in the positive direction when the announcement of dividend in creased and abnormal returns in the negative direction when the announcement of dividend decreased. The value of abnormal returns in a positive direction reflects the company's performance in good condition, and vice versa. This result indicates that dividend announcements are a signal and contain information relevant to investors in the investment decision making process.
\end{abstract}

\section{Keywords}

\section{JEL Classification}

\section{INTRODUCTION}

Dividend announcement is a policy where the management of the company will distribute a number of cash or cash equivalents to shareholders derived from company profits as a result of the company's fundamental performance to be distributed as dividends after deducting retained earnings. The policy is a signal to investors on the company's prospects, because companies that announce dividend distribution meet at least two criteria, namely: 1) the company is in favorable condition in the current period, and 2) the company is in liquid condition, meaning that the company has cash or cash equivalent can be shared with shareholders as a means of payment of dividends (Miller \& Modigliani, 1961; Simamora, 2000; Tandelilin, 2010; Sudana, 2011; Harmono, 2014; Sambodo et al., 2015; Shah \& Noreen, 2016; Puspitaningtyas, 2017, 2018).

Dividend announcements have an important meaning for investors, besides being able to give signals to the company's prospects, it is also predicted to influence market valuations (such as stock prices and stock returns). Signaling theory states that investors tend to react when getting signals from the company. Announcement of dividends is predicted to have information content that can be used to predict 
company profits and expected stock returns for investors so that it is useful as a consideration in the investment decision making process (Husnan, 2005; Amidu, 2007; Sielvia, 2009; Ali \& Chowdhury, 2010; Esomar, 2010; Mehndiratta \& Gupta, 2010; Slonski \& Zawadzki, 2012; Bodie et al., 2013; Zare et al., 2013; Menike, 2014; Sare et al., 2014; Chiang \& Lai, 2015; Scott, 2015; Harbi \& Bujang, 2016; Kouki, 2017; Mrzygłód \& Nowak, 2017; Puspitaningtyas, 2017, 2018).

Announcement of dividends can be fixed or changeable. These changes can be in the form of increases or decreases (Abdullah et al., 2002). The increase in dividends is interpreted as a signal of increasing company profits, and vice versa. Changes in the amount of dividends paid, both increases and decreases, are seen as signals where management expects future profits to change in the same direction. Increasing the amount of dividends paid is seen as a positive signal that encourages investors to offer higher stock prices while expecting a higher rate of return, and vice versa.

From the management side, one of the objectives of dividend distribution is as a signal intended to attract investors to invest their capital through the purchase or ownership of the company's shares. Signaling theory assumes the existence of information asymmetry, that managers (as internal parties) have accurate information about company values that may not be known by investors (as external parties). Because of the information asymmetry, it is necessary to signal to investors or other external parties through management policies, one of which is the announcement of dividends (Zare et al., 2013).

This study aims to determine and analyze the effect of dividend announcements, both increases and decreases, on stock returns. This study is intended to find empirical evidence about market reactions based on signaling theory on Indonesia Stock Exchange on the period 2017. That, the information content of dividend announcements is predicted to affect the company's stock returns. The results of this study are expected to provide benefits for investors as a basis for evaluating the company's prospects, as well as consideration in the investment decision making process. Puspitaningtyas (2018) states that investment decisions are related to investors' considerations about the decision to buy and sell shares, or maintain their share ownership.

The analysis of this study uses the event study method, which is a study that analyzes the market reaction to an event for information published as an announcement. The market reaction is indicated by a change in stock prices or by using abnormal returns and is predicted to influence stock returns. Furthermore, in order to test hypotheses, a different test paired sample $t$-test was carried out, which is intended to determine whether or not there are differences in market reactions to the announcement of the increase in the amount of dividends paid and announcements of the decrease in the amount of dividends paid to the company's stock returns. Jogiyanto (2009), Bodie et al. (2013), and Scott (2015) state that abnormal returns are the advantages of real returns and normal returns. Normal return is the return expected by investors. Thus, abnormal returns represent the difference between the actual return and the expected return.

If dividend announcements have a significant effect on company stock returns, the market will react when the announcement is received by giving a significant abnormal return to the market around the date of the announcement, and vice versa. Testing of abnormal returns uses a significance value of $5 \%$ $(\alpha=0.05)$. This test is conducted to determine the significance level of the difference in abnormal returns before and after the dividend announcement date, namely by comparing the significance level (sig.) of abnormal returns and the significance value of $5 \%(\alpha=0.05)$. If the level of significance (sig.) is less than 0.05 , it can be concluded that dividend announcements have a significant effect on stock returns, and vice versa.

Based on the description, the problems in this study are formulated as follows: 1) whether the announcement of dividends increase affects the stock return on companies listed in the Indonesia Stock Exchange 
on the period 2017; and 2) whether the announcement of dividend decrease has an effect on stock returns on companies listed in the Indonesia Stock Exchange on the period 2017. The inconsistency of some of the results of previous studies has motivated interest in conducting this study. The results of the study by Kartini (2001), Mulyati (2003), and Ratnawati et al. (2009) prove that the announcement of dividend payments has a significant effect on stock returns, whereas the study by Sambodo et al. (2015) shows that the announcement of dividend payments does not affect stock returns.

\section{LITERATURE REVIEW}

\subsection{Signaling theory and dividend policy}

Signaling theory is related to a signal derived from management policy, one of which is dividend policy. The policy is expected to signal to investors (as external parties) about company prospects and provide usefulness to investors as a consideration in the investment decision making process. If the content of an information is considered important by investors, then management can use the policy as a signal about value company, which can be seen from its influence on stock returns (Abdullah, 2002; Brigham \& Houston, 2010; Suwanna, 2012; Zare et al., 2013; Scott, 2015; Puspitaningtyas, 2017, 2018).

Signaling theory assumes that the manager has accurate information about the value of the company that may not be known to investors and he is also interested in maximizing his profits. This assumption is based on the existence of asymmetric information, which is a condition in which a party has information that may be unknown to another party. Asymmetric information will occur if the manager does not convey all the information he has about the value of the company, thus influencing investor judgment in the investment decision making process. The existence of asymmetric information triggers the signal to investors or the public through management policies to be very important. It is expected that the signal will provide information for investors about how he views the company's prospects. Signaling theory is concerned with reducing information asymmetry for investors. However, signal quality depends on the ability of investors to analyze information (Brau \& Carpenter, 2012; Zare et al., 2013; Su et al., 2014; Karasek \& Bryant, 2015; Shetty \& Sundaram, 2019).
Dividend policy is related to the distribution of profits to shareholders. The amount of dividends distributed is determined by the board of directors and authorized by the general meeting of shareholders, and must be stated as income in the year of acquisition. The announcement of dividend distribution contains information about the performance and prospects of a company (Simamora, 2000; Syamsuddin, 2011; Suwanna, 2012; Damayanti et al., 2017; Esana \& Darmawan, 2017).

Dividend policy relates to efforts to create a balance between current dividends and future growth. One of these policies is a decision about whether the profits obtained by the company during a period will be divided all or divided in part to pay dividends to its shareholders. On the one hand, if management decides to distribute profits obtained as dividends, it will reduce the amount of retained earnings. Reducing the amount of retained earnings means there is a decrease in the number of internal funding sources that will be used for company expansion. On the other hand, if management decides not to share its profits as dividends, it will reduce investors' interest in investing their funds in company stock ownership (Brigham \& Houston, 2010; Keown et al., 2010; Puspitaningtyas, 2017, 2018).

There are several forms of dividend policy (Halim, 2005; Keown et al., 2010), namely: 1) stable dividend policy, namely the same amount of dividend payments in each period. This policy is intended as a signal to investors (and prospective investors) that the acquisition of the company's net income is stable in each period; 2) dividend policy with the determination of the minimum amount of dividends plus certain extra amounts, namely the amount of dividend payments set at the minimum amount per share in each period and in increasing net income (better financial conditions), then management will pay extra dividends in addition 
from the minimum amount that has been set; 3 ) dividend policy by establishing a constant amount of dividend payout ratio. For example, management sets a constant amount of dividend payout ratio of $50 \%$. That is, that the amount of dividend per share to be paid in each period will fluctuate according to the acquisition of net income in each period; and 4) flexible dividend policy, namely the determination of the amount of dividends adjusted to the achievement of financial performance in each period.

\subsection{Announcement of dividends and stock returns}

Announcement of dividends or announcement dates is the date when management (directors) announce dividend payments. On that date, dividends are the company's liability and are recorded in the company's books. The announcement is predicted to trigger a market reaction (investor), which is reflected in the stock price movement, and has an impact on the expected return by investors (Simamora, 2000; Sularso, 2003; Akbar \& Baiq, 2010; Aamir \& Shah, 2011; Mahmood et al., 2011; Matharu \& Changle, 2015; Tastaftiani \& Khoiruddin, 2015; Legenzova, 2017, Truong et al., 2017). This is as revealed in the explanation of the signal dividend theory.

The dividend signal theory underlies the notion that the announcement of dividend payments has information content that encourages a reaction in stock price movements and has an impact on the investor's expected return. This theory explains that information about the announcement of dividend payments is a signal to investors about the company's prospects. The increase in the amount of dividends paid is considered a good or profitable signal ("good news"), thus giving rise to a reaction of stock price movements that tend to increase (positive). Conversely, a decrease in the amount of dividends paid is considered as a signal that is not good or not profitable ("bad news"), thus giving rise to a reaction of stock price movements that tend to decrease (negative) (Mulyati, 2003; Harbi \& Bujang, 2012; Tsuji, 2012; Scott, 2015; Legenzova, 2017).

Stock return is the expected profit from the amount of funds invested in the ownership of a company. Stock returns can be capital gains or yields. Capital gain is a form of return that is expected to be obtained by investors from the difference between the purchase price and the selling price of the stock, whereas yield is the percentage of dividends towards stock prices in the previous period (Jones, 2000; Husnan, 2005; Jogiyanto, 2009; Tandelilin, 2010; Puspitaningtyas, 2017).

Stock returns consist of: 1) actual return, i.e. a number of profits received from stock investment activities in a period; 2) expected return, namely a number of benefits expected to be obtained from stock investment activities in a period; and 3) abnormal returns, namely the difference between actual returns and expected returns (Jogiyanto, 2009; Bodie et al., 2013; Scott, 2015).

Based on this description, dividend announcements are predicted to contain information that is meaningful to investors. The market is predicted to react to the announcement. Therefore, dividend announcements are predicted to affect stock returns. If there is an increase in the amount of dividends paid to investors, it tends to be followed by an increase in stock prices and investors will likely revise the expected return in an increasing direction. Because, investors tend to interpret the increase in dividends as a positive signal, namely the improvement of the company's current and future performance. Conversely, if there is a decrease in the amount of dividends paid to investors, it tends to be followed by a decrease in stock prices and investors will likely revise their expected returns in a downward direction. Because, investors tend to interpret the decrease in dividends as a negative signal, namely the decline in current and future corporate performance (Jogiyanto, 2009; Bodie et al., 2013; Scott, 2015).

The hypotheses of this study are built on signaling theory. Modigliani and Miller (1961), Bodie et al. (2013), and Scott (2015) state that a dividend increase above normal is a signal for investors that companies have prospects that are good, and vice versa. Announcement of the increase in dividend payments is "good news" and tends to encourage investors to increase the expected rate of return. Conversely, the announcement of a decrease in dividend payments is "bad news" and tends to encourage investors to reduce the expected rate of return. The study hypotheses are also based on the results of previous studies, including studies 
by Kartini (2001), Mulyati (2003), Ratnawati et al. (2009) and Sambodo et al. (2015), which prove that markets react to dividend announcements, both increases and decreases. Thus, the study hypotheses are formulated as follows:

H1: Announcement of dividend increases affect stock returns on companies listed in Indonesia Stock Exchange on the period 2017.

H2: Announcement of dividend decreases affect stock returns in companies listed in Indonesia Stock Exchange on the period 2017.

\section{METHODOLOGY}

\subsection{Population and sample}

The population in this study are companies listed in Indonesia Stock Exchange on the period 2017, a total of 555 companies. Furthermore, sampling is done by purposive sampling method, which is sampling using certain criteria specified in this study. The sampling criteria in this study, namely: 1) selected companies that announced cash dividends in concecutive during the period 2016-2017 (2016 as the base year); 2) selected companies that do not conduct corporate actions other than the announcement of dividend payments on the period 2017; 3) selected companies that have complete data regarding dividend announcement dates, total dividends per share, and daily stock prices on the period 2017. Based on the sampling criteria, the number of samples in this study is 53 companies. Based on the number of samples, it is divided into two groups, namely: 1) companies that announce dividend increases of 34 companies, and 2) companies that announce dividend decrease of 19 companies.

\subsection{Operational definition and variable measurement}

Announcement of dividends is the date when the directors announce dividend distribution. At that date, the dividend becomes the company's liability and is recorded in the company's book. Announcements are usually made a week before dividends are paid.
Stock return is a profit expected to be obtained by investors from investment activities in a stock. Stock return information in this study is capital gains, because it is intended to see the market reaction to the announcement of dividends. Capital gains is a stock return whose acquisition is based on movements or changes in stock prices. Stock returns consist of four types, namely:

1) actual return, which is the profit received from an investment activity in a certain period. Actual return is used as the basis for determining the expected return in the future. This study measures actual return based on historical data, namely the difference between the current stock price and the previous stock price:

$$
R i_{t}=\frac{P i_{t}-P i_{t-1}}{P i_{t-1}},
$$

where $R i_{t}$ is the actual stock return $i$ in the pe$\operatorname{riod} t, P i_{t}$ is the price of stock $i$ in the period $t$, $P i_{t-1}$ is the price of stock $i$ in the period $t-1$;

2) expected return, which is the level of profit expected by investors in the future. Expected return is equal to normal return, meaning that the expected return is equal to the actual return that occurs in normal conditions. Expected return is estimated based on actual return before the event period during the estimation period. This study measures the expected return using the mean adjusted model. This model assumes that the expected return is constant, equal to the arithmetic average actual return previously in the estimation period:

$$
E\left(R i_{t}\right)=\frac{\sum_{t-6}^{t-15} R i_{t}}{T},
$$

where $E\left(R i_{t}\right)$ is the expected stock return $i$ in the period $t, T$ is the duration of the estimation period, which is for 10 days starting from $t-15$ to $t-6$;

3) abnormal return, which is the difference between actual return and expected return. Abnormal returns are measured by the formula:

$$
A R i_{t}=R i_{t}-E\left(R i_{t}\right)
$$

where $A R i_{t}$ is abnormal stock return $i$ in the period $t$; 
4) average abnormal return, which is the average difference between the actual return and expected return of all company samples analyzed daily during the event period. Testing for abnormal returns is not done on each share, but is carried out as a whole stock by testing the average abnormal return of all shares in a cross-sectional manner for each day in the event period by calculating the average of arithmetic:

$$
A R n_{t}=\frac{\sum_{i=1}^{n} A R i_{t}}{n},
$$

where $A R n_{t}$ is the average abnormal return $i$ in the period $t, n$ is the number of samples.

\subsection{Analytical method}

Analysis of this study uses the event study method. The event study is used to test the information content of an event that is published (in this study is a dividend announcement). If the announcement contains information, the market is predicted to react when receiving the announcement. The market reaction is indicated by the abnormal return around the date of the dividend announcement.

There are two periods in the application of the event study method, namely: 1) the estimation period, namely the period before the event. This period is used to estimate the expected return in the event period. The estimation is based on the actual return before the occurrence of the event during the estimation period, which is used to find the arithmetic mean for the entire actual return in the estimated period. There is no benchmark for the length of the estimation period, but some previous studies used periods of less than 100 days (minimum 10 days).

This study uses an event period of 10 days, namely: $t=-15-(-6)$. The event period is the period of occurrence of an event. This period is also called the observation period or event window. The length of this period depends on the type of event. If the event is a period whose economic value can be easily determined by investors, such as dividend announcements, the window period can be short, because in this case investors can react quickly. The window period commonly used in previous studies is 11 days (1 day around the date of announcement, which is 5 days before the date of the event up to 5 days after the date of the event).

The event period also involves the days before the event date to find out whether there is an information leak, namely whether the market already knows the contents of an information before it is officially published. The event period is used to see the market reaction to an announcement. The event period is divided into three parts (Jogiyanto, 2009), namely:

1) pre event, namely $t=t-5$ (5 days before the event);

2) event date, namely $t=0$ (event day);

3) post event, namely $t=t+5$ (5 days after the event).

Furthermore, in order to test the hypotheses, namely to determine whether or not there are differences in the number of abnormal stock returns as a market reaction before and after dividend announcements, a different test paired sample $t$-test is used. This analysis tool is intended to test whether or not there are differences for the two groups in pairs with the same subject but experience two different treatments (measurements).

Testing of abnormal stock returns given to the market uses a significance level of $5 \%$ $(\alpha=0.05)$. This test is conducted to determine the significance level of the difference in stock returns before and after dividend announcements by comparing the significance level (sig.) of abnormal returns with alpha $(\alpha)=5 \%$. If the level of significance (sig.) is less than 0.05 , the hypothesis is accepted, meaning that dividend announcements have a significant effect on stock returns of companies listed in Indonesia Stock Exchange on the period 2017. Conversely, if the level of significance (sig.) is more than 0.05 , the hypothesis is rejected, meaning that dividend announcements do not affect stock returns on companies listed in Indonesia Stock Exchange on the period 2017. 


\section{RESULTS}

\subsection{Analysis of the data using the event study method}

The event period for each company stock is set for 11 days, which is 5 days before the dividend announcement date, 1 day at the dividend announcement date, and 5 days after the dividend announcement date. For example, PT. Astra Agro Lestari Tbk (stock code: AALI) announces dividends on April 26, 2017, the event period for 11 days, which is 5 days before April 26, 2017, 1 day at the date of the announcement April 26, 2017, and 5 days after April 26, 2017.

Estimation period is set for 10 days before the event period. For example, the announcement of AALI stock dividends is April 26, 2017, the estimation period is 10 days before the event period, namely $t-15$ to $t-6$ from April 26, 2017.

Actual return is calculated based on capital gains value, which is the difference between the current stock price and the previous share price. The actual return calculation is done in the estimation period and event period. Actual return for each stock every day during the estimation period and every day in the event period is calculated by the formula: $R i_{t}=\left(P i_{t}-P i_{t-1}\right) / P i_{t-1}$. The following are the actual results of AALI stock returns (as one sample of this study) on day 15 in the estimated period and event period 2017:

$$
\begin{aligned}
& R A A L I_{d a y-15}=\frac{P A A L I_{d a y-15}-P A A L I_{d a y-16}}{P A A L I_{d a y-16}}= \\
& =\frac{14,100-14,150}{14,150}=\frac{-50}{14,150}=-0.003534 .
\end{aligned}
$$

Calculation of actual returns using this formula applies to all shares of this sample study on the estimated period and event period 2017.

Expected return is calculated using the mean adjusted model, which assumes that the expected return is constant, equal to the arithmetic average of the actual returns that occur every day during the estimated period. Expected returns are calculated by the formula:

$$
E\left(R i_{t}\right)=\frac{\sum_{t-6}^{t-15} R i_{t}}{T},
$$

The following is the result of calculating the expected return of AALI (as one sample of this study) on the estimated period 2017:

$$
\begin{aligned}
& E R A A L I_{t}=\left(R A A L I_{d a y-15}+R A A L I_{d a y-14}+\right. \\
& \left.\ldots+R A A L I_{d a y-6}\right) / 10= \\
& =(-0.003534+0.003546+0.04946+ \\
& +0.05724-0.00637-0.00641+0.006452- \\
& -0.00641-0.003226-0.04531) / 10= \\
& =\frac{0.045438}{10}=0.0045438 .
\end{aligned}
$$

Calculation of expected return using this formula applies to all shares of this sample study on the estimation period 2017.

Abnormal return is the difference between the actual return on each day in the event period and the expected return estimated from the arithmetic average of the actual return that occurred in the estimated period. Abnormal returns for each stock are calculated every day during the event period using the formula: $A R i_{t}=R i_{t}-E\left(R i_{t}\right)$.

The following is the result of calculating the abnormal return of AALI (as one sample of this study) on the estimated period 2017:

$$
\begin{aligned}
& A R A A L I_{d a y-5}=R A A L I_{d a y-5}-E R A A L I= \\
& =0.01695-0.0045438=0.0012405 .
\end{aligned}
$$

Calculation of abnormal return using this formula applies to all shares of this sample study on the estimation period 2017.

Average abnormal return is not calculated on each share, but is calculated as a whole stock by calculating the average abnormal return for the entire stock in a cross-section every day during the event period by calculating the overall arithmetic average of abnormal returns that occurs every day in the event period for the entire company in each group analyzed by the formula: 


$$
A R n_{t}=\frac{\sum_{i=1}^{n} A R i_{t}}{n} .
$$

The following is the result of calculating the average abnormal return for all shares of the company sampled in this study for each day of the period of events on the period 2017:

a) group of companies announcing dividend increases:

$$
\begin{aligned}
& A R n_{d a y-5}=\left(A R A A L I_{d a y-5}+A R A D M F_{d a y-5}+\ldots\right. \\
& \left.\ldots+A R \mathrm{TRST}_{d a y-5}\right) / 34= \\
& =\frac{0.0012405-0.0117565+\ldots+0.0154195}{34}= \\
& -\frac{0.4105037}{34}=-0.012074
\end{aligned}
$$

b) group of companies announcing dividend decreases:

$$
\begin{aligned}
& A R n_{d a y-5}=\left(A R A N T M_{d a y-5}+A R B B C A_{d a y-5}+\ldots\right. \\
& \left.\ldots+A R T S P C_{d a y-5}\right) / 19= \\
& =\frac{0.013329+0.03347+\ldots+0.030201}{19}= \\
& =\frac{0.1722394}{19}=0.009065 .
\end{aligned}
$$

Calculation of average abnormal return by using the formula applies to every day in the period of events on the period 2017, both for the group of companies that announce the increases in dividends and groups of companies that announce dividend decreases.

\subsection{Testing the hypothesis using a paired sample t-test}

Tests are carried out using SPSS version 20 with the following stages: entering the average abnormal return data obtained from the overall arithmetic average of abnormal returns that occur during the event period for the entire company sampled in this study in each group of samples analyzed. The following are the results of testing the hypotheses and discussing the results of the study.

\subsubsection{Announcement of dividend increase has an effect on stock returns}

For companies that announce dividend increases, dividend announcements are concluded to influence stock returns if there are positive and significant abnormal returns around the date of the dividend announcement. Table 1 presents the results of testing abnormal returns for companies that announce dividend increases.

Based on Table 1, for the days before the announcement date of the dividend increase in the event period, which was used as an option to find out whether there was an information leak before the announcement was officially published, indicating that there were no positive and significant abnormal returns that appeared in the days before date of announcement of dividend increase in the event period. Meanwhile, for the days after the announcement date the

\begin{tabular}{|c|c|c|c|c|c|c|c|c|c|}
\hline$t$ & $n$ & $\begin{array}{l}\text { Average abnormal } \\
\text { return }\end{array}$ & Sig. & Conclusion & $t$ & $n$ & $\begin{array}{l}\text { Average abnormal } \\
\text { return }\end{array}$ & Sig. & Conclusion \\
\hline-5 & 34 & -0.012074 & 0.216 & Insignificant & 0 & 34 & -0.005822 & 0.290 & Insignificant \\
\hline-4 & 34 & -0.005564 & 0.158 & Insignificant & 1 & 34 & 0.038614 & 0.032 & Significant \\
\hline-3 & 34 & 0.008011 & 0.229 & Insignificant & 2 & 34 & 0.019755 & 0.002 & Significant \\
\hline-2 & 34 & 0.000213 & 0.980 & Insignificant & 3 & 34 & 0.013071 & 0.089 & Insignificant \\
\hline \multirow[t]{2}{*}{-1} & 34 & 0.002030 & 0.816 & Insignificant & 4 & 34 & 0.010043 & 0.028 & Significant \\
\hline & & & & & 5 & 34 & 0.008308 & 0.070 & Insignificant \\
\hline
\end{tabular}
dividend increase in the event period shows that there are positive and significant abnormal returns with a significance level of less than 5\% (sig. <0.05), namely: $t+1=0.032$; $t+2=0.002$ and $t+4=0.028$. These results

Table 1. Different test results before and after announcement of increase in dividends based on average abnormal return on the period 2017

Source: Result of the study. 
Table 2. Different test results before and after announcement of decreases in dividends based on average abnormal return on the period 2017

\begin{tabular}{|c|c|c|c|c|c|c|c|c|c|}
\hline \multicolumn{10}{|c|}{ Source: Result of the study } \\
\hline$t$ & $n$ & $\begin{array}{l}\text { Average abnormal } \\
\text { return }\end{array}$ & Sig. & Conclusion & $t$ & $n$ & $\begin{array}{l}\text { Average abnormal } \\
\text { return }\end{array}$ & Sig. & Conclusion \\
\hline-5 & 19 & 0.009065 & 0.280 & Insignificant & 0 & 19 & -0.005903 & 0.467 & Insignificant \\
\hline-4 & 19 & 0.024396 & 0.186 & Insignificant & 1 & 19 & -0.028588 & 0.004 & Significant \\
\hline-3 & 19 & -0.002777 & 0.690 & Insignificant & 2 & 19 & -0.016782 & 0.009 & Significant \\
\hline-2 & 19 & -0.002600 & 0.742 & Insignificant & 3 & 19 & -0.017997 & 0.000 & Significant \\
\hline-1 & 19 & 0.007045 & 0.238 & Insignificant & 4 & 19 & -0.028192 & 0.002 & Significant \\
\hline & & & & & 5 & 19 & -0.021119 & 0.000 & Significant \\
\hline
\end{tabular}

prove, the hypothesis which states that the announcement of dividend increase has an effect on acceptable stock returns (H1 accepted).

These results indicate that the announcement of the increase in dividends contains information for investors and there is no leak of information to the market before the announcement is officially published. This indication is strengthened by the absence of positive and significant abnormal returns in the days before the announcement date of the dividend increase in the event period. Positive and significant abnormal returns appear in the days after the announcement date of the dividend increases in the event period.

This result supports the dividend theory revealed by Miller and Modigliani (1961) and support some of the results of previous studies including Jayaraman and Shastri (1993) and Virda and Karlina (2009), which prove that the announcement of dividend increases is considered a profitable signal, so it will encourage market participants to revise their expected returns in an increasing direction.

\subsubsection{Announcement of dividend decrease has an effect on stock returns}

For companies that announce a decrease in dividends, dividend announcements are concluded to influence stock returns if there are negative and significant abnormal returns around the date of the dividend announcement. Table 2 presents the results of testing abnormal returns for companies that announce dividend decreases.

Based on Table 2, the days before the announcement date of the dividend decreases in the event period were used as an option to find out wheth- er there was an information leak before the announcement was officially published, indicating that there were no negative and significant abnormal returns that appeared in the days before the date of announcement of the decrease in dividends in the period of the event. Meanwhile, the days after the announcement date of the dividend decreases in the event period show that there are negative and significant abnormal returns with a significance level of less than 5\% (sig. $<0.05$ ), namely: $t+1=0.004 ; \quad t+2=0.009$; $t+3=0.000 ; t+4=0.002$ and $t+5=0.000$. These results prove the hypothesis, which states that the announcement of dividend decreases has an effect on acceptable stock returns ( $\mathrm{H} 2$ is accepted).

These results indicate that the announcement of dividend decreases contains information for investors and there is no information leak to the market before the announcement is officially published. This indication is strengthened by the absence of negative and significant abnormal returns in the days before the announcement date of the dividend decreases in the event period. Negative and significant abnormal returns appear in the days after the announcement date of the dividend decreases in the event period.

This result supports the dividend theory revealed by Miller and Modigliani (1961), which states that the announcement of dividend decreases is considered as a disadvantageous signal, so it will encourage market participants to revise their expected return in a downward direction. However, the results of this study do not support the results of the study of Virda and Karlina (2009), which shows that the announcement of dividend decreases does not affect stock returns. 


\section{CONCLUSION}

Based on the results of analysis and discussion, it was concluded that the market reacts to the announcement of dividends, both increases and decreases in dividends. The market reaction is indicated by the existence of abnormal return values. The value of positive and significant abnormal return when the announcement of dividend increased, while the value of negative and significant abnormal return when the announcement of dividend decreased. The value of abnormal returns in a positive direction reflects the company's performance in a good (or profitable) condition, and vice versa. Thus, based on the perspective of signaling theory, the results of this study prove empirically that dividend announcements are a signal and contain information relevant to investors as a consideration in the investment decision making process.

\section{REFERENCES}

1. Aamir, M., \& Shah, S. Z. A. (2011). Dividend Announcements and the Abnormal Stock Returns for the Event Firm and Its Rivals. Australian Journal of Business and Management Research, 1(8), 72-76. Retrieved from http:// www.ajbmr.com/articlepdf/ AJBMR_18_11iln8a9.pdf

2. Abdullah, N. H., Rashid, R. A., \& Ibrahim, Y. (2002). The Effect of Dividend Announcements on Stock Returns for Companies Listed on the Main Board of the Kuala Lumpur Stock Exchange. Malaysian Management Journal, 6(1\&2), 81-98. Retrieved from https://core.ac.uk/download/ pdf/12116278.pdf

3. Abdullah, S. (2002). Free Cash Flow, Agency Theory and Signaling Theory: Concept and Empirical Research. Jurnal Akuntansi dan Investasi, 3(2), 151 170 [in Indonesian]. Retrieved from http://journal.umy.ac.id/index.php/ai/article/view/812/936

4. Akbar, M., \& Baiq, H. H. (2010). Reaction of Stock Prices to Dividend Announcements and Market Efficiency in Pakistan. The Lahore Journal of Economics, 15(1), 103-125. Retrieved from http:// www.lahoreschoolofeconomics.edu.pk/EconomicsJournal/ Journals/Volume\%2015/Issue\%20 1/5\%20Akbar_and_Baig\%20EDITED\%20AC.pdf

5. Ali, M. B., \& Chowdhury, T. A (2010). Effect of Dividend on Stock Price in Emerging Stock Market: A Study on the Listed
Private Commercial Banks in DSE. International Journal of Economics and Finance, 2(4), 52-64. https:// doi.org/10.5539/ijef.v2n4p52

6. Amidu, M. (2007). How Does Dividend Policy Affect Performance of the Firm on Ghana Stock Exchange? Investment Management and Financial Innovations, 4(2), 103-112. Retrieved from https://www.researchgate.net/ publication/286355892_How_ does_dividend_policy_affect_ performance_of_the_firm_on_ Ghana_Stock_exchange

7. Bodie, Z., Kane, A., \& Marcus, A. J. (2013). Investment (10th ed.). New York: McGraw-Hill Education.

8. Brau, J. C., \& Carpenter, J. T. (2012). Small-Firm Uniqueness and Signaling Theory. Journal of Business, Economics \& Finance, 1(1), 50-63. Retrieved from http:// www.pressacademia.org/archives/ jbef/v1/i1/5.pdf

9. Brigham, E. F., \& Houston, J. F. (2010). Fundamental of Financial Management (Indonesian version). Jakarta: Salemba Empat.

10. Chiang, Y., \& Lai, B. (2015) Dividend Payout Policy Decision: The Role of Foreign Ownership. Investment Management and Financial Innovations, 12(2), 205-213. Retrieved from https:// businessperspectives.org/journals/investment-managementand-financial-innovations/ issue-2-cont-7/dividend-payoutpolicy-decision-the-role-of-foreign-ownership
11. Damayanti, R., Marwati, F. S., \& Widayanti, R. (2017). Dividend Policy Analysis Based on Lintner's Theory. AGREGAT: Jurnal Ekonomi dan Bisnis, 1(2), 183-194. Retrieved from https://journal. uhamka.ac.id/index.php/agregat/ article/view/825

12. Esana, R., \& Darmawan, A. (2017). Effects of Dividend Policy and Investment Decisions on Company Values and Their Impact on Profitability $t+1$ : Study on Consumer Goods Industry Sub-Sector Registered on the Indonesia Stock Exchange Period 2006-2016). Jurnal Administrasi Bisnis, 50(6), 201-210 [in Indonesian]. Retrieved from http://administrasibisnis.studentjournal.ub.ac.id/index.php/jab/ article/view/2098/2490

13. Esomar, M. J. F. (2010). Investor Reaction to Announcement of Increase and Decrease in Dividends on the Indonesia Stock Exchange. Soso-Q, 2(2), 6-28 [in Indonesian]. Retrieved from http://etd.repository.ugm.ac.id/ index.php?mod=penelitian_detail \&sub=PenelitianDetail\&act $=$ view $\&$ typ $=h t m l \& b u k u \_i d=48494$

14. Halim, A. (2005). Investment Analysis [in Indonesian]. Jakarta: Salemba Empat.

15. Harbi, A., \& Bujang, I. (2012). Dividend Announcement Effects on Malaysian Stock Market Return: New Empirical Evidence using Panel Data Approach. The Business \& Management Review, 3(1), 374-384. Retrieved from 
http://www.abrmr.com/myfile/ conference_proceedings/Con_ Pro_12310/51.pdf

16. Harbi, A., \& Bujang, I. (2016). Dividend announcements effects on stock market returns: a comparative study between conventional and Shariah compliant stocks on Bursa Malaysia. Journal of Business and Retail Management Research (JBRMR), 11(1), 92-102. Retrieved from https://www.researchgate. net/publication/311823525_Dividend_announcements_effects_on_ stock_market_returns_A_comparative_study_between_conventional_and_Shariah_compliant_stocks_on_Bursa_Malaysia

17. Harmono (2014). Financial Management Based on the Balanced Scorecard Theory, Case and Business Research Approaches. Jakarta: PT. Bumi Aksara.

18. Husnan, S. (2005). Basics of Portfolio Theory and Securities Analysis. Yogyakarta: BPFE-UGM.

19. Jayaraman, N., \& Shastri, K. (1993). The Effects of the Announcements of Dividend Increases on Stock Return Volatility: The Evidence from the Options Market. Journal of Business Finance \& Accounting, 20(5), 673-685. https://doi. org/10.1111/j.1468-5957.1993. tb00283.x

20. Jogiyanto, H. (2009). Portfolio Theory and Investment Analysis. Yogyakarta: BPFE-UGM.

21. Jones, C. P. (2000). Investments Analysis and Management (6th ed.). New York: Jhon Willey and Sons Inc.

22. Karasek, R., \& Bryant, P. (2015). Signaling Theory: Past, Present, and Future. Electronic Business Journal, 14(12), 550-558.

23. Kartini (2001). Analysis of Shareholders Reaction Against Announcement of Changes in Dividend Payments at the Jakarta Stock Exchange. Jurnal Siasat Bisnis, 2, 121-142 [in Indonesian].

24. Keown, A.J., Scott, D.F., Martin, J.D., \& Petty, J.W. (2010). Financial Management [Indonesian version]. Jakarta: Salemba Empat.
25. Kouki, M. (2017). Earnings and Dividend Announcements: Are They Interactive? Evidence from the French Context. International Journal of Economics and Financial Issues, 7(1), 387-393. Retrieved from https://www.researchgate. net/publication/312031827_Earnings_and_Dividend_Announcements_Are_They_Interactive_Evidence_from_the_French_Context

26. Legenzova, R., Jurakovaitè, O., \& Galinskaité, A. (2017). The Analysis of Dividend Announcement Impact on Stock Prices of Baltic Companies. Central European Business Review, 6(1), 61-76. https://doi. org/10.18267/j.cebr.173

27. Mahmood, S., Sheikh, M. F., \& Ghaffari, A. Q. (2011). Dividend Announcements and Stock Returns: An Event Study on Karachi Stock Exchange. Interdisciplinary Journal of Contemporary Research in Business, 3(8), 972-981. Retrieved from https://journal-archieves13.webs. com/972-981.pdf

28. Matharu, S. K., \& Changle, R. (2015). An Empirical Study of Stock Prices' Sensitivity to Dividend Announcements. Pasific Business Review International, 8(3), 83-90. Retrieved from https:// www.semanticscholar.org/paper/ An-Empirical-Study-of-StockPrices-'-Sensitivity-to-MatharuChangle/6c645697c4af4b13e16493 6ea9f2365d71c87b44

29. Mehndiratta, N., \& Gupta, S. (2010). Impact of Dividend Announcement on Stock Prices. International Journal of Information Technology and Knowledge Management, 2(2), 405-410. Retrieved from http:// www.csjournals.com/IJITKM/ PDF\%203-1/47.pdf

30. Menike, MGPD (2014). Stock Price Reactions to the Dividend Announcement in the Emerging Market: Case in the Colombo Stock Exchange Sri Lanka. European Journal of Business and Management, 6(12), 111-118. Retrieved from https://www.iiste. org/Journals/index.php/EJBM/ article/view/12525
31. Miller, M. H., \& Modigliani, F. (1961). Dividend Policy, Growth, and the Valuation of Shares. Journal of Business, 34(4), 411-433. Retrieved from http://www.jstor. org/stable/2351143

32. Mrzygłód, U., \& Nowak, S. (2017). Market reactions to dividends announcements and payouts. Empirical evidence from the Warsaw Stock Exchange. Contemporary Economics, 11(2), 187-204. Retrieved from https:// papers.ssrn.com/sol3/papers. cfm?abstract_id=3176998

33. Mulyati, S. (2003). Reaction of Stock Prices to Changes in Cash Dividend and Yield Dividends at the Jakarta Stock Exchange. Jurnal Siasat Bisnis, 8(2), 233-249 [in Indonesian]. Retrieved from https://journal.uii.ac.id/JSB/article/view/1016/948

34. Puspitaningtyas, Z. (2017). Effect of Moderating Dividend Policy in the Effect of Profitability on Firm Value. Jurnal Akuntansi, Ekonomi dan Manajemen Bisnis, 5(2), 173180 [in Indonesian]. Retrieved from http://jurnal.polibatam.ac.id/ index.php/JAEMB/issue/view/71

35. Puspitaningtyas, Z. (2018). Ability of Net Income in Predicting Dividend Yield: Operating Cash Flow as a Moderating Variable. Archives of Business Research, 6(1), 226-234. Retrieved from https://www.researchgate.net/ publication/322817575_Ability_ of_Net_Income_in_Predicting Dividend_Yield_Operating_Cash_ Flow_as_a_Moderating_Variable

36. Ratnawati, Sumiati, \& Triyuwono, I. (2009). Impacts of Dividend Announcement on the Return, Return Variability, and Activities of Stock Trading Volume. Wacana, 12(4), 712-724 [in Indonesian].

37. Sambodo, S. A., Efni, Y., \& Halim, E. H. (2015). Effect of Dividend Announcement on Abnormal Returns and Stock Liquidity in Companies Listed on the Indonesia Stock Exchange (Case Study of LQ-45 Company Groups for the Period of February to July 2013). JOM FEKON, 2(1), 1-9 [in Indonesian]. 
38. Sare, Y. A., Pearl-Kumah, S., \& Salakpi, A. (2014). Market Reaction to Dividend Initiation Announcements on the Ghana Stock Exchange: the Case of Industrial Analysis. Asian Economic and Financial Review, 4(4), 440-450. Retrieved from www.aessweb.com/pdf-files/ aefr\%204(4),\%20440-450.pdf

39. Scott, W. R. (2015). Financial Accounting Theory (7th ed.). Toronto, Ohio: Pearson Education Canada, Inc.

40. Shah, S. A., \& Noreen, U. (2016). Stock Price Volatility and Role of Dividend Policy: Empirical Evidence from Pakistan. International Journal of Economics and Financial Issues, 6(2), 461472. Retrieved from http://www. econjournals.com/index.php/ijefi/ article/view/1752

41. Shetty, S., \& Sundaram, R. (2019). Funding Acquisition Drivers for New Venture Firms: Diminishing Value of Human Capital Signals in Early Rounds of Funding. Problems and Perspectives in Management, 17(1), 78-94. http://dx.doi.org/10.21511/ ppm.17(1).2019.08

42. Sielvia, A. A. (2009). The Effect of Initiation Dividends and Omisi Dividends on Stock Returns in Indonesia Stock Exchange. (in Indonesian). Jurnal Siasat Bisnis, 13(2), 113-128. Retrieved from https://media.neliti.com/media/ publications/84749-ID-pengaruhdividen-inisiasi-dan-dividen-om.pdf

43. Simamora, H. (2000). Accounting Base for Business Decision Making [in Indonesian]. Jakarta: Salemba Empat.

44. Slonski, T., \& Zawadzki, B. (2012). The Impact of a Surprise Dividend Increase on a Stocks Performance - the Analysis of Companies Listed on the Waesaw Stock Exchange. Operations Research and Decisions, 2, 45-54. Retrieved from http:// cejsh.icm.edu.pl/cejsh/element/ bwmeta1.element.desklighte869acd6-2667-4d5b-bab0$881671 \mathrm{e} 28686$

45. Su, W., Peng, M. W., Tan, W., \& Cheung Y. (2014). The Signaling Effect of Corporate Social Responsibility in Emerging Economies. Journal of Business Ethics, 134(3), 479-491 https://doi. org/10.1007/s10551-014-2404-4

46. Sudana, I. M. (2011). Corporate Financial Management: Theory and Practice [in Indonesian]. Surabaya: Erlangga.

47. Sularso, R. A. (2003). The Effect of Dividend Announcement on Changes in Share Prices (Return) Before and After Ex-Dividend Date in Jakarta Stock Exchange. Jurnal Akuntansi \& Keuangan, 5(1), 1-17 [in Indonesian].

48. Suwanna, T. (2012). Impacts of Dividend Announcement on Stock Return. Procedia - Social and Behavioral Sciences, 40, 721725. https://doi.org/10.1016/j. sbspro.2012.03.255

49. Syamsuddin, L. (2011). Corporate Financial Management [in Indonesian]. Jakarta: Rajawali Pers.

50. Tandelilin, E. (2010). Investment Analysis and Portfolio Management [in Indonesian]. Yogyakarta: BPFE - UGM.

51. Tastaftiani, M., \& Khoiruddin, M. (2015). Analysis of the Effect of Announcement of Cash Dividends on Abnormal Return and Variability of Stock Returns. Management Analysis Journal, 4(4), 333-340 [in Indonesian]. Retrieved from http://journal. unnes.ac.id/sju/index.php/maj

52. Truong, N. X., Huong, D. M., \& Anh, N. T. V. (2017). Stock Price Reaction to Cash Dividend Announcements in Vietnam. Journal of Economic Development, 24(2), 74-89. Retrieved from http://www.vjol.info/index.php/ ed/article/view/34070

53. Tsuji, C. (2012). A Discussion on the Signaling Hypothesis of Dividend Policy. The Open Business Journal, 5, 1-7. Retrieved from https://benthamopen.com/ contents/pdf/TOBJ/TOBJ-5-1.pdf

54. Virda, Y., \& Karlina. (2009). Effect of Dividend Announcement on Stock Return Before and After Ex-Dividend Date in Indonesia Stock Exchange. Proceeding PESAT (Psikologi, Ekonomi, Sastra, Arsitektur \& Sipil), 3, B72-B79 [in Indonesian].

55. Zare, R., Kiafar, H., Kanani, M. A., \& Farzanfar, F. (2013). Dividend Policy from the Signaling Perspective and its Effects on Information Asymmetry among Management and Investors. Research Journal of Applied Sciences, Engineering and Technology, 6(21), 4090-4097. Retrieved from http:// maxwellsci.com/print/rjaset/v64090-4097.pdf 